\author{
AGNIESZKA TAMBOR \\ (D) https://orcid.org/0000-0003-1536-8986 \\ Uniwersytet Śląski w Katowicach \\ Katowice
}

\title{
Półka filmowa 2019
}

\author{
Film shelf 2019
}

\begin{abstract}
The paper presents the most important and the most interesting Polish films of 2019. The text covers titles such as: Corpus Christi, Icarus. The Legend of Mietek Kosz (Nie)znajomi, Mr Jones, Politics, Their Lucky Stars, Spoor, and Playing Hard. The author presents particular films from a point of view interesting for foreigners - people learning Polish as a foreign language and interested in Polish culture.
\end{abstract}

Key words: film, Polish films, 2019, cinema

Rok 2019 to kolejny udany - przynajmniej frekwencyjnie - czas dla polskiego kina. Ponownie znaleźliśmy się w piątce najlepszych filmów nominowanych do Oscara w kategorii najlepszy film nieanglojęzyczny (obecnie: najlepszy film zagraniczny). Jeszcze lepiej pod tym względem (choć niekoniecznie gdy idzie o jakość produkcji) wygląda początek roku 2020. Niestety - jak twierdzą producenci - dla jakości polskiego kina wraz z początkiem roku 2020 większość sieci kinowych zdecydowała się na drastyczną obniżkę cen biletów.

Jeśli tak radykalna obniżka cen biletów się utrzyma, (...) to powinna zmusić polskich producentów do zmniejszenia budżetów filmów średnio o $35 \%$. To oznacza również gwałtowny spadek honorariów o taki sam procent. Już widzę chętnych do tego, żeby pracować za mniej niż $2 / 3$ dotychczasowego wynagrodzenia... Fakty są jednak takie, że w tej sytuacji nawet produkowanie najbardziej komercyjnego kina stanie się nieopłacalne. Czy Polacy się z tego uciesza? Na pewno kino amerykańskie będzie miało się świetnie¹.

\footnotetext{
${ }^{1}$ https://sporwkinie.blogspot.com/2020/03/kina-obnizaja-ceny-biletow-produkcja.html ?fbclid=IwAR2UxlHAY5Y8xYL8DxL4cSjBFimp4tp-8kl7scgfUmxee-cxZ1GB5WTqnTM [dostęp: 12.03.2020].
} 
Przeliczając tę obniżkę bardziej wyraźnie dla widza - jeśli cena biletu spada o połowę, to aby wszystko utrzymało się na dotychczasowym poziomie, widzów na filmie musiałoby być dwa razy więcej. W przypadku najbardziej komercyjnych produkcji oznaczałoby to konieczność zwiększenia oglądalności filmów z 2 milionów na 4 miliony... Wszyscy zdajemy sobie sprawę, że taka granica jest właściwie nieosiagalna (w ostatnich latach jedynie filmowi Kler udało się zgromadzić pięciomilionową publiczność). Matematyka, która wygląda zatem nieźle z perspektywy widzów, niezbyt obiecujące efekty zapowiada w przyszłości (i to zapewne nieodległej) producentom oraz dystrybutorom.

\section{Boże Ciało}

Zdecydowanie najgłośniejszym (i najlepszym) filmem tego roku jest polski kandydat do Oscara, czyli Boże Ciało Jana Komasy. Film, niestety, przegrał walkę o tę prestiżową nagrodę z południowokoreańskim obrazem Parasite 3 , nie umniejsza to jednak w żaden sposób jego wartości. Historia chłopca z poprawczaka, który marzy o zostaniu księdzem, a w rezultacie - w wyniku „nieporozumienia” - posługę kapłańską zaczyna pełnić, może wydawać się na pierwszy rzut oka dość kontrowersyjna. Taki - mniej lub bardziej krytyczny - sposób przedstawiania tematów „religijnych” często nie jest dobrze odbierany w wielu krajach. Polacy do religii maja stosunek specyficzny - jest ona jednym z najczęściej (obok polityki) poruszanych tematów na rodzinnych i towarzyskich spotkaniach. Jednak seans filmu Komasy szybko rozwiewa wątpliwości. Boże Ciało to tak naprawdę przekaz o młodości, odwadze, umiejętności wybaczania i miłości. Nietrudno sobie wyobrazić, iż tragiczna historia, która jest tłem losów głównego bohatera, mogłaby być prawdziwa. Społeczność miejscowości, do której trafia bohater, jest podzielona, pełna nieskrywanej i skrywanej nienawiści i wzajemnych pretensji. Młody człowiek, podający się za księdza, robi wszystko, aby mieszkańcy miasteczka pogodzili się z przeszłością i ze sobą. Jednocześnie odkrywa przed widzami smutną prawdę o małomiasteczkowej mentalności, w której utrzymanie pozorów za wszelką cenę jest ważniejsze od potrzebującego pomocy sąsiada.

\footnotetext{
${ }^{2}$ Film Joon-ho Bonga otrzymał 4 statuetki, w tym za: najlepszy film międzynarodowy i najlepszy film roku.
} 
Nie jest to film o kościele i duchownym - fałszywym czy prawdziwym, ale film o nas. W Boşym Ciele na pierwszy plan wychodzą najgorsze przywary polskiego społeczeństwa - łatwość w osądzaniu, społeczny ostracyzm oraz ciche przyzwolenie na patologie. To także obraz, który mówi o tym, jak wiele kwestii w naszym życiu uzależnionych jest od naszych własnych decyzji i dlaczego dawanie „drugiej szansy” nie powinno być passé. ${ }^{3}$

Jednym z najsilniejszych punktów filmu jest z całą pewnością obsada aktorska. Bartosz Bielenia odkrywa przed widzami zupełnie nowe światy - tej postaci nie można było zagrać lepiej, gorzej ani inaczej. Bielenia nie gra - on po prostu jest. Gdyby tylko Amerykańska Akademia Filmowa była ciałem, delikatnie mówiąc, mniej skostniałym, Bielenia mógłby się doczekać nominacji do Oscara za najlepszą rolę męską. Z kolei aktorka, która wybija się w obrazie Komasy ponad przeciętność, to Aleksandra Konieczna.

Gospodyni księdza to stop wszystkich milczących księżych gospodyń, księżych matek, w ogóle gospodyń i matek. Zaciskają zęby, sznurują usta, ale wiele widza, zbyt wiele widzą. Istnieją bardzo mocno, tylko mało kto potrafi je zauważyć4.

\section{Ikar. Legenda Mietka Kosza}

Najnowszy film Macieja Pieprzycy Ikar. Legenda Mietka Kosza to niezwykle ciekawa opowieść o Mieczysławie Koszu - legendzie polskiej szkoły jazzu. Ta formacja muzyczna, której powstanie datuje się na połowę lat 50. XX w. znana stała się przede wszystkim dzięki takim twórcom, jak: Krzysztof Komeda, Michał Urbaniak, Tomasz Stańko czy Jan „Ptaszyn” Wróblewski.

Dziś trudno zrozumieć fenomen Mieczysława Kosza. W pamięci starszych miłośników jazzu i osób zawodowo związanych z tą muzyką pozostaje postacią nieomal mityczną. Wywodzący się z głębokiej prowincji, obciążony niepełnosprawnością artysta ${ }^{5}$ potrafil rozwinąć oryginalny język muzyczny w czasach, gdy kontakt z głównym nurtem światowego

\footnotetext{
${ }^{3}$ https://www.granice.pl/publicystyka/boze-cialo-recenzja-filmu/1372/1 [dostęp: 11.02.2020].

${ }^{4}$ https://kultura.onet.pl/film/recenzje/oscary-2020-boze-cialo-z-jedna-nominacja-recen zja-filmu-jana-komasy/xlvkqb9 [dostęp: 11.02.2020].

${ }_{5}$ Mieczysław Kosz w wieku 12 lat stracił wzrok.
} 
jazzu był w Polsce bardzo ograniczony. Jego gra odbiła się echem także w Europie. Był zapraszany na koncerty nawet na tak prestiżowych imprezach, jak festiwal w Montreux (...). A przecież za jego życia ukazała się tylko jedna autorska płyta długogrająca! Jego pianistykę można jeszcze usłyszeć na składance New Faces in Polish Jazz, a także jako akompaniament na krążku wokalistki Marianny Wróblewskiej. I to wszystko! W dzisiejszych czasach, gdy dorobek fonograficzny jest podstawa istnienia artysty w świadomości mediów i słuchaczy, to nie do pomyślenia. Jednak wtedy, na przełomie lat 60. i 70., kiedy Kosz rozpoczynał karierę, było inaczej6.

Kosz zapomniany przez szerszą publiczność był absolutnym objawieniem polskiej jazzowej sceny muzycznej. Jego legendę przywołuje w swoim filmie Maciej Pieprzyca i robi to doskonale. Film jest przeżyciem wizualnym, ale przede wszystkim muzycznym, i to, co warto podkreślić, nie tylko dla osób, które kochają jazz. Utwory muzyka charakteryzują się wpływami klasycznymi, a także folkowymi. Niestety, życie wielkich artystów naznaczone jest często piętnem nieszczęścia - tak też jest i w tym przypadku. Kosz popadł w alkoholizm, a pogłębiające się poczucie samotności i dojmującego smutku8 spowodowało, iż w maju 1973 roku wypadł (lub wyskoczył) przez okno. Nie do końca wiadomo, czy był to krok świadomy, czy spowodowany zbyt dużą ilością alkoholu. Śmierć w wieku 29 lat i wspomniany już niewielki w gruncie rzeczy dorobek muzyczny spowodowały, iż postać Kosza szybko odeszła w zapomnienie. Pozostaje jednak nadzieja, iż film Pieprzycy i niezwykła kreacja rewelacyjnego Dawida Ogrodnika9 dadzą mu nowe wspaniałe życie.

\section{(Nie)znajomi}

Kilka zaprzyjaźnionych par spotyka się pewnego ciepłego wieczoru na kolacji. Każdego dręczą inne kłopoty, każdy ma inny pomysł na ich rozwiązanie. Sympatyczne towarzystwo, pyszne jedzenie i zbliżające się zaćmienie księżyca

\footnotetext{
${ }^{6}$ https:// hi-fi.com.pl/sylwetki-muzyczne-lista/1090-mieczys $\%$ C5 $\% 82$ aw-kosz- $\%$ C5\%BCy cie-jest-dramatyczn $\%$ C4\%85-przygod $\%$ C4\%85.html [dostęp: 15.02 .2020 ].

${ }^{7}$ Kosz uwielbiał muzykę Bacha, Beethovena, Chopina i Liszta.

8 Sam Kosz mówił, że „tylko smutek jest piękny”.

9 Ogrodnik staje się w polskim kinie specjalistą od ról „trudnych”. Wystarczy przypomnieć jego występy w filmach Chce sie àyć (p. „Postscriptum Polonistyczne” 2014, nr 1) czy Ostatnia rodzina (p. „Postscriptum Polonistyczne” 2017, nr 1).
} 
maja pomóc rozluźnić się i zapomnieć o troskach codzienności. W rzeczywistości jest to jednak początek próby sił, testu na szczerość, wierność, oddanie i cierpliwość. Ktoś proponuje grę: do zakończenia wieczoru wszystkie wiadomości, maile i rozmowy staną się publiczne, przy stole nie będzie tajemnic. Czy taka igraszka z prywatnością może skończyć się dobrze?10

Przytoczone słowa nie dotyczą wcale filmu (Nie)znajomi - jest to opis włoskiego filmu Dobrze sie kłamie w mitym towarzystwie, na podstawie którego została nakręcona polska produkcja. Nasz remake odpowiada oryginałowi właściwie w każdym calu - stąd możliwość podmiany opisów, a nawet fragmentów recenzji obu filmów. Co ciekawe, włoski pomysł na scenariusz okazał się na tyle nośny, iż na taki krok jak Polacy zdecydowali się twórcy pochodzący z kilku krajów, m.in. z Francji, Hiszpanii i Turcji. Należy zatem zadać sobie pytanie: Czy świetny włoski film stracił w rodzimej wersji na wartości?

Na szczęście nie - z cała pewnością jest to zasługa polskiej obsady. Tomasz Kot, Maja Ostaszewska, Łukasz Simlat, Michał Żurawski, Wojciech Żołądkiewicz, Kasia Smutniak ${ }^{11}$ i Aleksandra Domańska dają niezwykły popis umiejętności aktorskich. Scenariusz, podobnie zresztą jak np. Ržž Romana Polańskiego, cały ciężar osadza właśnie na grze aktorskiej. Jedno pomieszczenie, brak jakichkolwiek efektów specjalnych i scenariusz oparty wyłącznie na rozmowach nie pozostawia pola na żadne błędy. Polscy aktorzy wypadają wyśmienicie - każdy z nich ma w filmie swoje pięć minut, podczas których popisują się aktorskim kunsztem, jak gitarzysta grający solo na najważniejszym w życiu koncercie. To te momenty nadają filmowi specyficznie polskiego uroku i nieco odróżniaja go od włoskiego pierwowzoru ${ }^{12}$.

Koniec końców (Nie)znajomi to ta sama, pozbawiona niechcianego moralizatorstwa, ale stawiająca solidny fundament pod zadawanie pytań, pełna przenikliwych spostrzeżeń opowieść o regular everyday normal guys, egoistach i hipokrytach, usprawiedliwiających oszustwa dążeniem do własnego spokoju i szczęścia. Teatr, na którego scenie zabawa i śmiechy zmieniają się w oskarżenia i płacz ${ }^{13}$.

${ }^{10}$ https://www.filmowa.net/content/1659.html?view=event [dostęp: 15.02.2020].

11 Polska modelka mieszkająca od wielu lat we Włoszech pojawia się zarówno w oryginale, jak i w polskiej wersji filmu.

$12 \mathrm{~W}$ filmie znaleźć można także kilka zmian scenariuszowych, których nie opisuję, aby nie popsuć seansu. Ponadto będą one miały znaczenie wyłącznie dla osób, które obejrzały lub obejrzą oba filmy.

13 https://naekranie.pl/recenzje/nie-znajomi-recenzja-filmu [dostęp: 15.02.2020]. 
Niezależnie od tego, którą wersję (a może obie?) wybierze widz, seans nie będzie czasem zmarnowanym. Wręcz przeciwnie, na pewno każdego skłoni do pewnych przemyśleń i szybkiego rzutu okiem w pamięć własnego telefonu komórkowego. A pytanie, na które szczerze odpowiedzieć powinien każdy po zakończeniu filmu, brzmi: Czy ty zagrałbyś w tę grę?

\section{Obywatel Jones}

Kiedy piszę o nowym filmie Agnieszki Holland, właściwie nie jest on już nowy. Premiera najnowszego obrazu reżyserki pt. Szarlatan odbyła się bowiem podczas Międzynarodowego Festiwalu Filmowego w Berlinie w 2020 roku. Zanim jednak historia czeskiego uzdrowiciela Jana Mikoláška14 trafi do kin, warto przyjrzeć się filmowi Obywatel Jones. To historia dziennikarza, który wskutek wywiadu z Adolfem Hitlerem zyskuje swoje pięć minut sławy i postanawia napisać artykuł o modernizacji Związku Radzieckiego. W tym celu udaje się w podróż do Moskwy i tam chce przeprowadzić wywiad z Józefem Stalinem. Nic nie idzie jednak po jego myśli, w efekcie czego trafia na Ukrainę, na której szaleje „Hołodomor” (czyli wielki głód ${ }^{15}$ ). Od tego momentu tytułowy Gareth Jones staje się jednym z niewielu obcokrajowców, którzy zobaczyli na własne oczy tę potworną zbrodnię i którzy zdecydowali się opowiedzieć o niej światu. Jego niewygodne dla wielu osób artykuły relacjonujące wydarzenia na Ukrainie nie spotkały się wcale z przyjaznym odbiorem. Jednym z jego najzagorzalszych krytyków stał się Walter Duranty - korespondent „New York Timesa” w Moskwie. Na szczęście było też wielu takich, którzy uwierzyli - m.in. George Orwell, który zainspirowany opowieściami Jonesa, napisał jedną z najważniejszych książek XX w. Folwark żwierzecy.

Obywatel Jones nie jest z cała pewnością najlepszym filmem Agnieszki Holland. Pomysł na film był bardzo ciekawy i film mógłby być hitem,

${ }^{14}$ „Akcja filmu rozgrywa się w drugiej połowie XX w. W tym czasie nazwisko Mikoláška znano prawie w całej Europie. Jego pacjentem był m.in. angielski król Jerzy VI i Antonín Zápotocký - premier Czechosłowacji w latach 1948-1953, a od 1953 r. - prezydent. Mikolášek uratował jego kończynę przed amputacją, co dało mu niebywałą polityczną ochronę. Ta niestety skończyła się wraz ze śmiercią Zápotockýego - wówczas zorganizowano proces, który pozbawił go majątku i praw obywatelskich" (https://www.onet.pl/film/onetfilm/szar latan-zwiastun-nowego-filmu-agnieszki-holland/130z2cd,681c1dfa [dostęp: 17.02.2020]).

${ }^{15} \mathrm{Na}$ temat tej ,zapomnianej” zbrodni XX w. powstało wiele utworów, m.in. wstrząsająca książka Anne Applebaum pt. Cžerwony głód. 
żeby to jednak osiagnąć, trzeba bardziej skoncentrować się na bohaterach. Polska reżyserka przedstawia Jonesa jak typowego naiwnego Brytyjczyka, który po odkryciu prawdy poświęci wszystko na jej ujawnienie. To postać zagrana niezwykle płasko i jednostajnie. Mało tu człowieka z krwi i kości, mało emocji, brak czegoś, co mogłoby porwać tłumy. A w porównaniu z nim Ada i Duranty jeszcze mocniej przypominaja podróbki ludzi wycięte w kartonie. Problemem nie jest to, że Gareth Jones to zwykły człowiek, a nie superbohater. Agnieszka Holland po prostu nie mówi o nim niczego ciekawego ${ }^{16}$.

Wstrząsające obrazy umierających z głodu ukraińskich wsi są więc, niestety, nieco przyćmione tą właśnie naiwnościa i jednowymiarowością postaci głównego bohatera. Brakuje też z cała pewnościa przemycenia (choćby np. w scenach kłótni z Durantym albo w procesie pisania artykułów) informacji o przyczynach „Hołodomoru”, o którym - wbrew pozorom - niewielu ludzi wie cokolwiek. Patrząc na film z perspektywy takiej właśnie osoby, można się obawiać, iż okaże się on mniej niż zajmujący.

\section{Całe szczęście}

W przypadku polskich komedii romantycznych trudno mówić o walce o palmę pierwszeństwa w konkursie na najlepszy film. Mowa jest tu raczej o konkurencji na najmniej żenujący scenariusz i jego możliwe jak najmniej drętwe odegranie. Jak wypada w tym zestawieniu „,najnowszy film twórców Listów do M. 3 i Podatku od mitości”? Na tle tegorocznej konkurencji - przyzwoicie. Fakt, że ściganie się z filmami takimi, jak Miszmasz, czylli kogel-mogel 3 czy Jak poślubić milionera nie stawiało poprzeczki zbyt wysoko.

Cate szczeście to historia muzyka orkiestry symfonicznej, który poznaje celebrytkę, w związku z czym jego życie zmienia się diametralnie. Główny bohater i jego syn błyskawicznie „oddają się w jej ręce”, a co dalej, to już łatwo się domyślić. Nie tak łatwo, bo „nieoczekiwany” zwrot akcji na pewno zaskoczy każdego widza. Początkowe sceny przywodzą na myśl hit Notting Hill z Julią Roberts i Hugh Grantem - Piotr Adamczyk nie najgorzej naśladuje nieporadnego księgarza, na tym, niestety, pozytywne inspiracje się kończa.

\footnotetext{
16 https://www.spidersweb.pl/rozrywka/2019/10/25/obywatel-jones-recenzja-agnieszkaholland-film/ [dostęp: 15.02.2020].
} 
Trudno znaleźć gdziekolwiek pozytywną recenzję filmu Całe sz̨çeście. Autorzy recenzji czy opisów krytykują każdy aspekt filmu. Nie wszystkie zarzuty jednak, jak się wydaje, są w pełni zawinione. Takim aspektem byłoby na przykład zarzucanie najnowszej produkcji Tomasza Koneckiego braku oryginalności. Konia z rzędem temu, kto wskaże oryginalną komedię romantyczną - cechą charakterystyczną tego gatunku (jak się wydaje bardziej nawet niż innych) jest trwanie. Trudno powiedzieć, czy wynika to z lenistwa twórców, czy z samej formuły gatunku, który najwyraźniej pozostawia mniej pola do kreatywności niż dramat czy nawet horror. Nie aż tak krytyczne są głosy widzów, którzy za pozytyw uznają m.in. grę dwunastoletniego Maksymiliana Balcerowskiego. Znajdując zatem średnią tych ocen, jeśli trzeba byłoby wybrać najlepszy premierowy film 2019 roku, reprezentujący gatunek komedii romantycznej, to wybór mógłby paść na Cate sz̨ræésie.

\section{Polityka}

Patryk Vega i Wojciech Smarzowski to specjaliści od pokazywania Polski w krzywym zwierciadle. Obaj robią to dość bezpardonowo, różnią się jednak nieco w swoich wizjach poziomem (choćby tym artystycznym). Polityka, która weszła na ekrany kin w 2019 r., reklamowana była jako film, który zdemaskuje polską scenę polityczną itd. Jak to zwykle bywa w przypadku takich produkcji, szumne obietnice pozostają raczej niespełnione. Tak też jest z Politykeq. To raczej zestaw gagów (bardzo zanurzonych zresztą w aktualnych wydarzeniach politycznych, których za dwa, trzy lata nikt nie będzie w stanie rozszyfrować) niż film, który domagałby się logicznie poprowadzonego scenariusza. „Chociaż mówi się, że najlepsze scenariusze pisze życie, to właśnie scenariusz jest najsłabszą stroną Politykę"17. Poszczególne części filmu to skecze kabaretowe bez większego polotu i jakiegokolwiek wkładu własnego twórców tej produkcji. W efekcie widzowie dostali zatem zwiastun, w którym pokazano wszystkie „śmieszne” sceny i film, który nie jest ani zabawny, ani kontrowersyjny.

Reżyser połączył kilka przestarzałych memów udostępnianych na grupkach propolskich z kawałami znanymi z przedostatniej strony magazy-

17 https://plus.gloswielkopolski.pl/polityka-recenzja-filmu-patryka-vegi-ktory-mial-wywroc ic-scene-polityczna-ale-nie-ma-czym/ar/c13-14398621 [dostęp: 15.02.2020]. 
nów pokroju „Pani Domu”. W filmie pada każdy przestarzały mem, który kiedyś wyskoczył Wam na tablicy, bo udostępnił go ktoś z Waszej bliższej lub dalszej rodziny. ${ }^{18}$

Jeśli ktoś chciałby obejrzeć ciut śmieszniejszą satyrę polityczna, zdecydowanie więcej uwagi winien poświęcić serialowi Ucho prežesa, stworzonemu przez Roberta Górskiego z Kabaretu Moralnego Niepokoju. Serial, choć równie jak Polityka efemeryczny, jeśli chodzi o opowiadane historie, trzyma jednak zdecydowanie lepszy poziom dowcipu i gry aktorskiej. Filmy Vegi kręcone są szybko, bez zwracania większej uwagi na detale - chodzi w nich głównie o to, aby doraźnie wyśmiać, wskazać i napiętnować pewne problemy i patologie. Gdyby Patryk Vega chciał zapisać się złotymi zgłoskami w historii polskiego kina, nie byłaby to z cała pewnością dobra droga. Jednak zakładając, że jego celem jest raczej zarobienie dużych i szybkich pieniędzy, nie ma większego sensu ocenianie poziomu artystycznego jego kolejnych produkcji.

\section{Zabawa, zabawa}

Kinga Dębska to polska reżyserka, która w dwóch filmach - Moje córki krowy i Zabawa, zabawa - udowodniła, że ma niezłą rękę do dramatów obyczajowych. Jej najnowszy film to historia kilku kobiet, które mają problemy $\mathrm{z}$ alkoholem.

Sposób, w jaki Dębska przygląda się bohaterkom, (...) czyni z niej jedną z najwrażliwszych polskich autorek. Nie ma tu ani efektownego ironizowania, ani połajanki z moralnej stratosfery. Reżyserka nie przegina też w druga stronę i nie czyni z alkoholiczek ofiar wielowiekowej tradycji. Zadowala się empatią, dla której znalazła ekwiwalent w filmowym języku. ${ }^{19}$

Zabawa, rabawa jest dość wstrząsającym obrazem tego, dokąd może człowieka doprowadzić nadużywanie alkoholu. Silnym punktem produkcji są z cała pewnością aktorzy (a w tym przypadku przede wszystkim aktorki) od-

\footnotetext{
18 https://www.filmawka.pl/polityka-recenzja/ [dostęp: 16.02.2020].

19 https://www.filmweb.pl/reviews/recenzja-filmu-Zabawa+zabawa-22083 [dostęp: 16.02. 2020].
} 
twarzający główne role. Wyjątkowe brawa należą się Dorocie Kolak, Agacie Kuleszy i Marii Dębskiej, które w niezwykły sposób portretują wykształcone kobiety sukcesu ${ }^{20} \mathrm{z}$ bagażem życiowym w postaci ukrywanego, przed całym światem i sobą, ogromnego problemu.

Żadna nie zdaje sobie sprawy ze swojego problemu i reaguje gwałtownie na jakiekolwiek próby zwrócenia uwagi czy ratunku. To w tym miejscu Zabawa, zabawa staje się filmem autentycznym, bo nie da się wyczuć w poruszeniu kwestii odrobiny fałszu. Da się uwierzyć w to, jak każda postać radzi lub też nie radzi sobie $z$ uzależnieniem $\mathrm{i}$ jak to się $\mathrm{w}$ trakcie filmu rozwija. Czy trzeba spaść na dno, by uratować się od tego? A do tego pokazane jest też współuzależnienie bliskich, którzy nie mogą nic zrobić, by pomóc. Trio aktorek błyszczy, sprawiając, że każdy wątek ma swoją tożsamość, unikalność i emocje. W każdym czuć, jakbyśmy po prostu oglądali coś z życia wziętego. Pomaga w tym spokojna, obserwująca sytuację kamera, która nigdy nie idzie w tanie efekciarstwo w kwestii alkoholizmu czy przesadne skakanie $\mathrm{z}$ historii na historięę

\section{Pokot $^{22}$}

Z pewnością filmem wartym przywołania w tegorocznym zestawieniu jest Pokot Agnieszki Holland. Mimo iz film został nakręcony w 2017 roku, Literacka Nagroda Nobla dla Olgi Tokarczuk przywróciła go z powrotem na ekrany wielu (nie tylko polskich) telewizorów i komputerów. Agnieszka Holland należy z całą pewnością do oscarowych weteranów ${ }^{23}$. W roku 2017 reżyserka ponownie miała szansę na nominację, jednak tym razem jej najnowszy film Pokot przegrał walkę z obrazami ze Szwecji, Danii, Iranu, Australii i Niemiec.

Wokół kandydatury Pokotu zrobiło się (...) głośno w wyniku petycji, którą do ministra kultury i dziedzictwa narodowego Piotra Glińskiego wy-

\footnotetext{
${ }^{20}$ Jedna to lekarka $\mathrm{z}$ wielkimi sukcesami na koncie, druga to pani prokurator, a trzecia to ambitna studentka.

21 https://naekranie.pl/recenzje/zabawa-zabawa-recenzja-filmu-3517538 [dostęp: 16.02.2020].

22 Prezentowany opis jest nieco zmodyfikowaną wersją fragmentu artykułu Półka filmowa sezonu 2017 opublikowanego w numerze 1. „Postscriptum Polonistycznym” z 2018 roku.

${ }^{23}$ Trzy nominacje do tej prestiżowej nagrody za filmy: Gorækie żniwa (1986), Europa, Europa (1992) i W ciemności (2012).
} 
stosowali członkowie Stowarzyszenia im. Biskupa Kajetana Sołtyka oraz Klubu Magna Polonia Ziemia Kłodzka. Domagali się oni wycofania filmu Agnieszki Holland z walki o nominację, ponieważ uważają, że jest on antykatolicki i antypolski ${ }^{24}$.

Być może zatem jednym z powodów, dla których Polacy musieli tym razem obejść się smakiem, stały się właśnie kontrowersje, jakie film wzbudzał w kraju. Większość osób, oczywiście, odrzucała zarzuty stawiane w petycji, uznając je za absurdalne, nie zmienia to jednak faktu, że odbiły się one dość szerokim echem w Polsce i na pewno nie pozostały niezauważone poza jej granicami. O czym zatem jest Pokot, że udało mu się tak zbulwersować część polskich widzów? Jest to adaptacja powieści Prowadź swój plug præę kości umarlych Olgi Tokarczuk. Film i książka opowiadają historię mieszkającej na prowincji kobiety. Główna bohaterka, Janina Duszejko, po odkrytej we wsi serii morderstw na kłusownikach i myśliwych, rozpoczyna swoje własne śledztwo.

Chciałabym, żeby to myślistwo tu mocno zabrzmiało, ale to historia starszej kobiety, która toczy walkę z patriarchalnym światem. Myślistwo jest metafora władzy, zawsze tak było. To jest klucz do rozumienia mechanizmów, z którymi i dziś mamy do czynienia ${ }^{25}$

- tak historię charakteryzuje jej autorka, Olga Tokarczuk.

Bardzo trudno jest opisać Pokot i dość trudno jest wyrazić jednoznaczna opinię na jego temat. Z całą pewnością wielkim atutem filmu są aktorzy Agnieszka Mandat, Jakub Gierszał, Andrzej Grabowski i inni, a to już na pewno wystarczający powód, aby poświęcić czas dziełu Agnieszki Holland.

\section{Filmografia}

Boże Ciało, reż.: Jan Komasa, scen.: Mateusz Pacewicz, zdj.: Piotr Sobociński jr., wyst.: Bartosz Bielenia, Aleksandra Konieczna, Eliza Rycembel, Tomasz Ziętek, Łukasz Simlat.

Ikar. Legenda Mietka Kosza, reż.: Maciej Pieprzyca, scen.: Maciej Pieprzyca, zdj.: Witold Płóciennik, muz.: Leszek Możdżer, wyst.: Dawid Ogrodnik, Jowita Budnik, Wiktoria Gorodeckaja, Maja Komorowska, Justyna Wasilewska, Piotr Adamczyk.

${ }^{24}$ http:/ / film.onet.pl/wiadomosci/oscary-2018-najlepszy-film-nieanglojezyczny-walka-o-n ominacje/kr3hnh [dostęp: 18.01.2018].

25 https://pl.wikipedia.org/wiki/Pokot_(film) [dostęp: 18.01.2018]. 
(Nie)znajomi, reż:: Tadeusz Śliwa, scen.: Katarzyna Sarnowska, Tadeusz Śliwa, zdj.: Michał Dąbal, wyst.: Tomasz Kot, Maja Ostaszewska, Lukasz Simlat, Michał Żurawski, Wojciech Żołądkiewicz, Kasia Smutniak, Aleksandra Domańska.

Obywatel Jones, reż.: Agnieszka Holland, scen.: Andrea Chalupa, zdj.: Tomasz Naumiuk, wyst.: James Norton, Vanessa Kirby, Peter Sarsgaard, Joseph Mawle, Krzysztof Pieczyński.

Polityka, reż.: Patryk Vega, scen.: Olaf Olszewski, zdj.: Norbert Modrzejewski, wyst.: Andrzej Grabowski, Zbigniew Zamachowski, Maciej Stuhr, Daniel Olbrychski, Janusz Chabior.

Całe szcz̧ście, reż.: Tomasz Konecki, scen.: Marcin Baczyński, Mariusz Kuczewski, zdj.: Tomasz Madejski, wyst.: Roma Gąsiorowska, Piotr Adamczyk, Maksymilian Balcerowski, Joanna Liszowska.

Pokot, reż:: Agnieszka Holland, Kasia Adamik, scen.: Olga Tokarczuk, Agnieszka Holland, zdj.: Jolanta Dylewska, Rafał Paradowski, wyst.: Agnieszka Mandat, Wiktor Zborowski, Jakub Gierszał, Andrzej Grabowski.

Zabawa, zabawa, reż.: Kinga Dębska, scen.: Kinga Dębska, Mika Dunin, zdj.: Andrzej Wojciechowski, wyst.: Dorota Kolak, Agata Kulesza, Maria Dębska, Marcin Dorociński, Barbara Kurzaj, Mirosław Baka.

\section{Netografia}

https://hi-fi.com.pl/sylwetki-muzyczne-lista/1090-mieczys $\%$ C5\%82aw-kosz- $\%$ C5\%BCyciejest-dramatyczn $\%$ C4\%85-przygod $\%$ C4\%85.html [dostęp: 15.02.2020].

https://kultura.onet.pl/film/recenzje/oscary-2020-boze-cialo-z-jedna-nominacja-recenzja-fil mu-jana-komasy/xlvkqb9 [dostęp: 11.02.2020].

https://naekranie.pl/recenzje/nie-znajomi-recenzja-filmu [dostęp: 15.02.2020].

https://naekranie.pl/recenzje/zabawa-zabawa-recenzja-filmu-3517538 [dostęp: 16.02.2020].

https://www.filmawka.pl/polityka-recenzja/ [dostęp: 16.02.2020].

https://www.filmowa.net/content/1659.html?view=event [dostęp: 15.02.2020].

https://www.filmweb.pl/reviews/recenzja-filmu-Zabawa+zabawa-22083 [dostęp: 16.02.2020].

https://www.granice.pl/publicystyka/boze-cialo-recenzja-filmu/1372/1 [dostęp: 11.02.2020].

https://www.onet.pl/film/onetfilm/szarlatan-zwiastun-nowego-filmu-agnieszki-holland/130 z2cd,681c1dfa [dostęp: 17.02.2020].

https://www.spidersweb.pl/rozrywka/2019/10/25/obywatel-jones-recenzja-agnieszka-holla nd-film/ [dostęp: 15.02.2020].

https://sporwkinie.blogspot.com/2020/03/kina-obnizaja-ceny-biletow-produkcja.html?fbc lid=IwAR2UxlHAY5Y8xYL8DxL4cSjBFimp4tp-8k17scgfUmxee-cxZ1GB5WTqnTM [dostęp: 12.03.2020]. 
Agnieszka Tambor - dr, Instytut Nauk o Sztuce, Uniwersytet Śląski w Katowicach, Katowice, Polska. Adiunkt w Instytucie Nauk o Sztuce Uniwersytetu Śląskiego w Katowicach.

Była współtwórczynią i jest obecnie zastępcą dyrektora kierunku międzynarodowe studia polskie (na poziomie licencjackim oraz magisterskim). Od wielu lat współpracuje ze Szkołą Języka i Kultury Polskiej. Wykłada na Podyplomowych Studiach Kwalifikacyjnych Nauczania Kultury Polskiej i Języka Polskiego jako Obcego (edycje w Katowicach, Rzymie, Berlinie i Dublinie). Przez wiele lat kierowała egzaminami wstępnymi z języka polskiego dla osób chcących studiować na Uniwersytecie Śląskim. Prowadziła także warsztaty dla nauczycieli za granicą m.in. w Stanach Zjednoczonych, Kanadzie, Kazachstanie i Chinach. Pracowała przy dwóch multimedialnych projektach do nauki języka polskiego: Europodians oraz Slavic Network. Jest autorką wielu artykułów i książek związanych z nauczaniem kultury polskiej i języka polskiego m.in.: Nowa Polska Półka Filmowa. 100 filmów, które każdy cudzoziemiec zobaczyć powinien, Polska Półka Filmowa. Krótkometrażowe filmy aktorskie $i$ animowane w nauczaniu języka polskiego jako obcego, (Nie)codzienny polski. Teksty i konteksty oraz Licz na Banacha (podręcznik do nauczania słownictwa specjalistycznego z zakresu nauk ścisłych). Prowadzi blog i kanał filmowy Polska Półka Filmowa:

https://www.youtube.com/channel/UCeXplj05NyRVcWKg85wOiTw, www.facebook.com/Polska-Półka-Filmowa-100108104897142

Kontakt: tamboragnieszka@gmail.com 